\section{Massive Benign Lingual Tonsil Hyperplasia and Tracheostomy}

Ognjen Cukic ${ }^{1}$, Sanja Nikolic ${ }^{1}$, Milan B. Jovanovic ${ }^{1,2}$

${ }^{1}$ Department of Othorinolaryngology, Clinical Hospital Center Zemun, Belgrade, Serbia

${ }^{2}$ Medical Faculty, University of Belgrade, Serbia

\section{Abstract}

We describe a case of excessive lingual tonsil hyperplasia in adult despite previous tonsillectomy which required initial tracheostomy to complete removal of lymphoid tissue. We discuss intubation difficulties in evaluation of airway.

Key words: Aneurysm, left ventricle, cormatrix

\section{Masivna benigna lingvalna tonzilarna hiperplazija i traheostomija}

\author{
Ognjen Cukic $^{1}$, Sanja Nikolic ${ }^{1}$, Milan B. Jovanovic ${ }^{1,2}$ \\ ${ }^{1}$ Department of Othorinolaryngology, Clinical Hospital Center Zemun, \\ Belgrade, Serbia \\ ${ }^{2}$ Medicinski fakultet Univerziteta u Beogradu
}

\section{Apstrakt}

Opisujemo slučaj prekomerne hipersplazije lingvalne tonzila kod odraslih uprkos prethodnoj tonzilektektomiji koja je zahtevala inicijalnu traheostomiju da bi se kompletno uklonilo limfoidno tkivo. Raspravljamo o poteškoćama u intubaciji u proceni disajnih puteva.

Ključne reči: Aneurizma, leva komora, Cormatrix

\title{
Introduction
}

A hyperplastic lingual tonsil is rare condition and may compromise the upper airway, particularly in the retrolingual area, and it can lead to severe complications such as cardiac arrest, cerebral anoxia, and death, primarily because of the risk of an unexpected difficult tracheal intubation ${ }^{1}$. Furthermore, lymhoid hiperplasia of the tongue closely resembles carcinoma and lymphoma, clinically or histopathologically ${ }^{2}$.

\section{Case report}

We report the case of a 54-year old woman affected by progressively developed disphagia for solid food but with no significant weight loss during the previous 2 years. The patient had had tonsillectomy when 5 years old because of recurrent episodes of tonsillar infection. Oropharyngeal examination revealed a smoothsurfaced, enormous overgrowth on the left side base of the tongue protruded toward the medial pharyngeal wall (Figure 1).

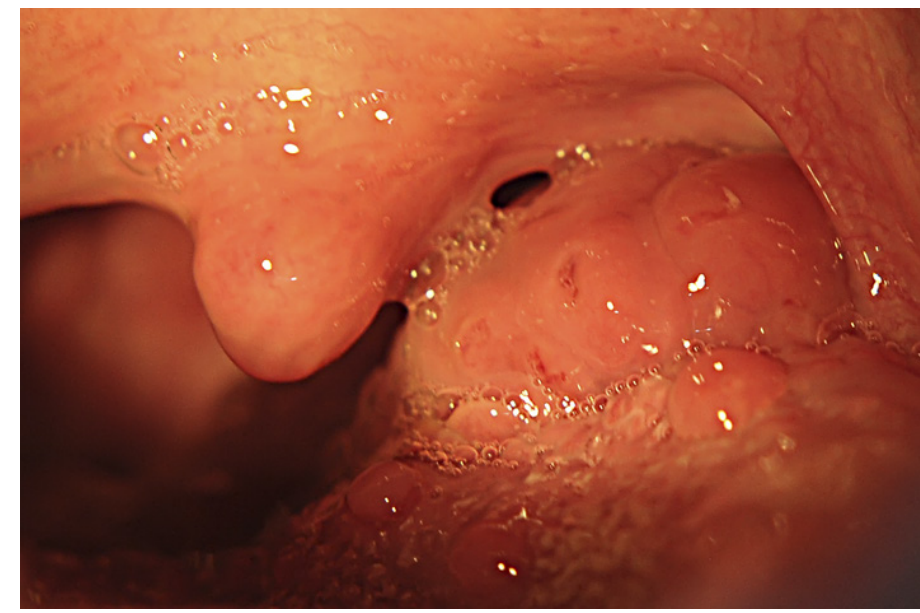

Figure 1. Oropharyngeal examination of the tongue base mass 
A computed tomography scan showed the lesion $/ 53,3 \mathrm{mmx} 38,8 \mathrm{~mm}$ ) had filled the entire vallecula and were causing the epiglottis to retroflex and approximate the posterior pharyngeal wall significantly narrowing airway and impeded the transit of the food (Figure 2.).

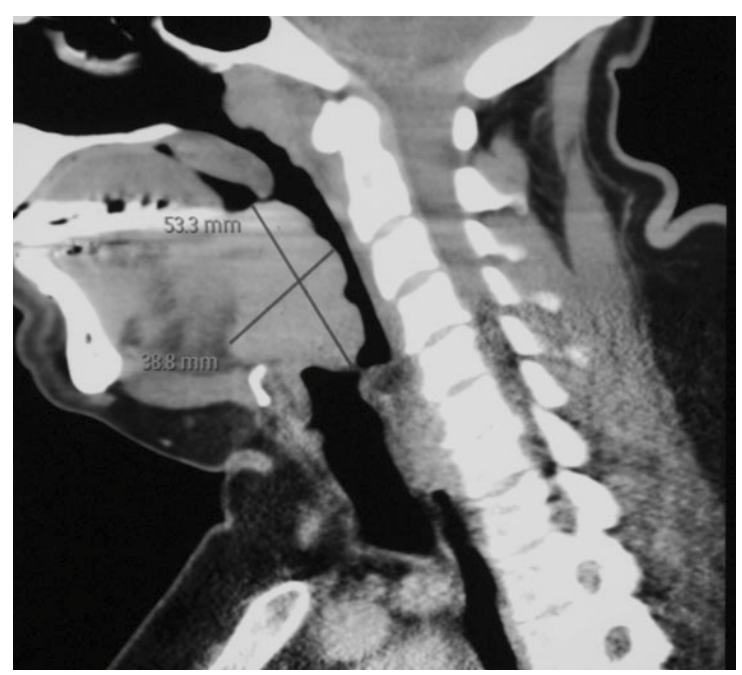

Figure 2. CT scan without contrast enhancement shows a bulky, expansive, oval mass with dimension

Because of intubation difficulties, a preoperative tracheostomy was performed. Tissue was removed via sharp dissection and electrocautery. Histopathologic examination showed that resected tissue consisted of reactive follicular hyperplasia. The operation totaly resolved the open airway and swallowing disturbance. The Ethic Committee of Clinical Hospital Center "Zemun", Faculty of Medicine, University of Belgrade approved this case report.

\section{Discussion}

To our knowledge, there are no previous reports of such massive benign lingual hyperplasia and inpossible intubation which required preliminary tracheostomy. Lymphoid lingual hyperplasia in adults, particularly after tonsillectomy, are usually asymptomatic. When present, symptoms rise due to mechanical compression/ obstruction and patients usually complain of non-specific symptoms such as tongue paraesthesia, dysphagia, and throat discomfort and dyspnea ${ }^{3}$. It is necessary to prepare a difficult airway management including laryngeal mask airway, fiberoptic bronchoscopy and transcutaneous tracheotomy set ${ }^{4,5}$. Macintosh laryngoscopy failed to expose a glottis by two experienced anesthesiologists. Rigid laryngoscopy could not visualize the epiglottis because of hypertrophied tonsillar tissue, and mask ventilation became difficult when spontaneous breathing stopped. Also, fiberoptic bronchoscopy through the nasal cavity in combination with jet ventilation not allowed nasotracheal intubation to be accomplished. Due to the large size ( $>5 \mathrm{~cm}$ in maximum diameter) and site of this limphoid tissue, it was decided to proceed with traheostomy in order to ensure complete removal of lesion.

\section{Conclusion}

Massive lingual tonsill hyperplasia is one risk factor for an unanticipated failed intubation not detectable during routine oropharyngoscopy that shoud be considered during a preliminary evaluation of airway. 


\section{References}

1. Ovassapian A, Glassenberg R, Randel GI, Klock A, Mesnick PS, Klafta JM. The unexpected difficult airway and lingual tonsil hyperplasia: a case series and a review of the literature. Anesthesiology 2002;97:124-32.

2. Spinou C, Kubba H, Konstantinidis I, Johnston A. Role of tonsillectomy in histology for adults with unilateral tonsillar enlargement. Br J Oral Maxillofac Surg 2005;43(2):144-7.

3. Friedman M, Wilson MN, Pulver TM, Golbin D, Lee GP, Gorelick G, Joseph NJ. Measurements of adult lingual tonsil tissue in health and disease. Otolaryngol Head Neck Surg 2010;142:520-5.

4. Patel DR. Enlarged palatine tonsil causing parasthesia to the posterior one-third of the tongue. Br J Oral Maxillofac Surg 1996;34:201-2.

5. Orhan ME, Gözübüyük A, Sizlan A, Dere U. Unexpected difficult intubation due to lingual tonsillar hyperplasia in a thoracotomy patient: intubation with the double-lumen tube using stylet and fiberoptic bronchoscopy. J Clin Anesth 2009;21:439-41.

Corresponding author:

Milan B. Jovanovic, Department of Otorhinolaryngology and Maxillofacial surgery, Clinical Hospital Center "Zemun", Vukova 911080 Belgrade, Serbia Emailmajov@eunet.rs

Phone +38163339915 